\title{
YOU FELL INTO THE RIVER AND I SAVED YOU!
}

\section{Reunion \#1}

It was my fault our families had to play with watermelon seeds instead of real poker chips because of course, earlier that day, I had flung some of the chips at the birch tree that shaded our living room, and I only regretted it later when my aunt mentioned she saw a bird choking on something.

A poker chip? I asked her.

Most likely, she said.

My uncle had brought his deluxe poker set from his house in North Carolina that I had visited once when I was eight. On the car ride back I wrote an essay, "My Favorite Place and Yeeeahhh It's a Real Place!" and in it I described each of the rooms in his house and the hokey watercolors he hung up in all the hallways that I had been enamored with at the time. I won a ribbon from my teacher a few weeks later that I kept clean and unwrinkled and pinned permanently to my special-occasions crushed velvet dress. My mother had taken a set of photos with me holding up my essay in my velvet dress and ribbon and sent them to my uncle, who in return took a set of photos of him holding up a sign that said Congratulations! over his mouth, which was so big and wide that even behind the white construction paper I could make out the faint contours of his smile.

Those days were long past. My uncle and my aunt had driven fourteen hours to see us before moving to Thailand for a job offer my uncle received to work on developing new face creams for men.

I don't understand, my mother said to my uncle the first night they arrived. What do men need face creams for? They're supposed to have terrible, rough-looking faces.

So did women before face creams were invented, I said.

She's got a great point, my uncle said, putting his arms around me. I shrugged them off and longed to be somewhere where I could say anything I wanted and still be left alone.

My cousins Annie and Tony were five and nine. They were going to go to boarding school in Massachusetts next year, and my family was going to visit once every month to give them things like milk candies and bottles and bottles of foul-smelling Chinese sauces. I was thirteen and didn't want 
to be involved in any of this, but I was a part of it, as always, and as always, everyone asked me all the time, What's wrong? Are you okay? Is something bothering you? At night, I flung my pillow against my mattress and prayed to my fake jade statue of the Guanyin goddess to give me a different face so that people would stop looking at my current one and asking me what was wrong.

On our last night together as two families, we decided to play poker. We had been playing for an hour, and Aunt Lili was beating everyone, and no one was good except her, and none of the betting was fun because of it, and between each play she turned to my brother and tousled his hair.

"He's ten years old, you know," I said to Aunt Lili under my breath. And then, to my brother, "Wash your hair, you degenerate. Seriously."

"Ten is still a baby," she responded, her eyes momentarily fixed on the flop. Her little darty eyes rankled my heart, made it sour like the last pickle in a decade-old jar of brine, and I knew there was nothing wrong about her eyes, darty or not, and I knew there was nothing anyone could do about the way their eyes darted just like how I couldn't do anything about the frown on my face, and how I didn't mean to start ninth grade with a face that looked like it wanted to spit on anyone who asked me a question, but there were moments like that when you were unable to be generous, and those were moments when you were as cold as the sum total of all the winters you've ever experienced, and that was why I said, "And middle age is, uh-oh, how have I not yet committed suicide." I was slurring from sneaking snips all night long from my mother's glass of Remy Martin.

"Say sorry," my mother said. "Ni gei nian nian suo sorry, now. Suo a."

"Nope," I said.

"Yes," everyone said, turning to me.

"No," I said, jumping onto the table and pointing a finger at my brother. "I was defending you. Why does she have to touch your hair? Is everyone here against me?" I stomped my feet on the table, scattering the watermelon seeds.

"Zang si dao le," my mother said.

"What are you saying, Jenny?" my father asked.

"You've ruined the entire game," my aunt Lili said.

"I wanna shoot you with this gun," my cousin Tony said, pointing his Lego gun at my face. "Boom, boom, boom, boom, boom, boom, boom, boom, boom, boom, boom, boom, boom, boom, boom-" 
“-Tony," my cousin Annie interrupted. "You done yet? You've killed her. Are ya happy now? You've killed our favorite cousin."

"See," I shouted, the Remy Martin coalescing into a magnetized scrap of shrapnel hurtling out of my stomach towards the light of the North Pole-was I standing anywhere significant? No, just standing on the table my father built when he was thirty-three and I was five and my mother was twenty-nine, a time when it was still thinkable for the three of us to spend entire afternoons walking down Fifth Avenue and stopping at every pay phone to check for change. My father used to lift me up and let me push my sticky, candy-coated fingers into the change slot. Ka-ching, I said when I felt Washington's raised, chiseled face, or the American eagle.

"See, some people still love me," I said, swallowing my vomity burp back down.

"Xia lai," my mother said.

"Get down," my father said.

"Xia lai, you'll hurt yourself," my uncle said.

"Xia lai, this table was never meant to feel your nasty feet," my aunt said.

"Don't listen to them," my cousin Annie said.

"Boom, boom, boom, boom, boom, boom," my cousin Tony said.

"You look like you're going to throw up," my brother said.

"Xia lai," my uncle said. "Annie and Tony might want to eat the rest of their dinner on this table later."

"And they're really particular about germs," Aunt Lili said.

"Jenny doesn't have germs," Annie said. "She smells like a rose."

My mother grabbed my ankles and yanked me off the table. I stumbled on my feet and hit my back against the table on my way down. "Shen jing bing la?" she asked.

"Yep," I said. "And it's all your fault." I rubbed my back, jumped to my feet, and climbed the stairs two by two all the way up to my room, slammed the door, and said, "Leave me alone," even though no one at all was coming up the stairs for me.

In my room, I grabbed my half-empty glass of soda and poured it in the shape of weaving triple helixes over my carpet. I pretended it was gasoline and that I was setting the whole house and my whole family on fire. I felt like I was about to say something significant, to proclaim that I was sorry for it all and sorry for having been born, and that I believed in God now and not just the five-dollar plastic Guanyin goddess that sat high on my shelf, but a God 
who made me want to be a better person, and I felt like I could be repentant, I could still rehabilitate my soul, purge my bitterness that I had no right to, but as soon as the sour bile of preserved duck eggs and lake shrimp and egg and tomato and scallion and rice and string beans and ground pork rolled up through my stomach and into my throat and out my mouth in the tiniest upward curving trajectory through the air before dragging itself down to my bare feet, I knew that nothing was going to change, I would pretend not to regret anything, I would remain angry, I would be angry in the morning and angry the next day, and even when I no longer had the strength for it, even when I was sure that I no longer wanted to feel like I was being rolled up into a fist, I would only become angrier when I realized that I was incapable of unclenching.

\section{Reunion \#2}

"The small days of living," my mother told me when I was twenty-two and about to leave home for the second time, "are the days when the whole family is gathered around the dinner table and your grandfather is at the head of the table and we are all listening to him talk about the old days. There's too much food on the table and everyone eats fast and afterwards, we all pick at the food until it's nearly gone and rub our stomachs. Your father loosens his belt and so do the other men. The women go to the bathroom often. We all drink more and more and more tea, and everyone becomes restless but we like it that way.

"Some of us want to leave, but no one leaves because your grandfather is a great storyteller. He's just slow. He takes his time and he doesn't notice visual cues, but you love to hear him talk, I love to hear him talk, we all love to hear him talk, even though we beg him not to pull out his earwax with a bobby pin when he's talking. Your father gets it from him," my mother said, not exasperated, but gleeful, happy to make this connection. "That's why he carries those clicking pens everywhere. It's so he can be anywhere in the world and pull out a pen and start scratching the earwax out of his ears."

"Your mom means the old days of living," my father said, explaining the only part of my mother's reminiscence that was in English. After he said it, it started to make sense to me. I didn't blame my mother for her verbal mishaps-she only learned English when she was thirty-five, and she wouldn't have learned it at all if she wasn't born beautiful and meant to stay that way for the rest of her life. There was a night when she went to the public library 
to check out Chinese books and a man approached her and offered to teach her English if she would agree to hold his hand at the beginning and end of each session. He scared her right away, the way he kept inching closer to her when talking so that she had to back up until she was against a wall, and then she had to slide sideways against the wall until she was backed up in a corner, but she said yes, despite feeling frightened by the desperation with which the man never blinked and the way he kept offering more and more things to convince her to take his offer, like a gourmet sandwich and soup at the start of each session, a can of soda or a dollar for her to buy a soda of her own choosing, as many pens and marble composition notebooks as she needed, used paperback classics and books on tape that she could use to study on her own time. Despite my mother's misgivings, she agreed to be tutored by him because no one in my family has ever been known to refuse free services.

"Remember those days?" my mother asked my father.

"I remember those days," my father said and asked me, "Do you remember those days?"

I don't remember those days. I was only one and two and three and four and four and a half and ten one year when I visited for four weeks, and twelve one year when I visited for three weeks, and fifteen one year when I visited for ten days, and nineteen another year when I visited for four days, and twenty-one another year when I visited for two weeks.

When I was twenty-one and visited for two weeks, my cousin Jing, who worked for a German pharmaceutical company where she corresponded with her boss in the form of handwritten letters in English that she faxed throughout the day, and worked weekends as a voice-dubbing actress for American cartoons that flopped in the U.S. but were big in Asia, explained to me some things about my grandfather.

"When he was younger, they sent him to a shoe factory to make boots for Mao's army. The factory was up in the mountains where it was very cold and cloudy. On his very first day he ran away. And it wasn't that he was a coward-although he was a bit of a coward — and it wasn't that he had envisioned some other way of serving his country. It was simply because he was lazy and he wanted to sleep, and he saw that if he stayed in the boot factory, he would only be given six hours a day to sleep and that wasn't nearly enough for him."

"Hee hee," I said, interrupting my cousin. "Now I know where I get my good genes from." 
"Right," she said. "So all he wanted to do was sleep. He hated working. So he ran all the way down this mountain until he found a tree to lie down against. He slept all through the afternoon and all through the night, and when it was morning, a high-up army commander found him sleeping underneath a tree with a pack of tobacco next to him and realized that the army probably couldn't use him, but the newspaper could, so he picked up our grandfather by his collar and made him the managing editor of the People's Liberation Army's newspaper, which you know is now the Jiefang Ribao, the oldest Communist newspaper in print."

"So his laziness got him a job."

"Exactly," my cousin said. "But you know how it is. This family has always been lucky. We've always had fortune on our side."

"This family," I repeated after her. "You're right. I never realized it, but you're right."

\section{Reunion \#3}

When I was ten, I went with my mother to visit our relatives in China for a month. I had just learned how to dry hump anything that was smooth and leathery and was disappointed when I got to China and found that everything, including the bed sheets and couch cushions, was rough and uncomfortable and smelled faintly of mold, piss, and shit. Everyone stared at me when I went outside, and waiters and shopkeepers asked my mom if I was deaf or dumb or mute or just plain stupid when I took too long to answer their questions.

In the evenings, I went to my grandmother's house and waited and ate oranges and grapes and crackers while the adults cooked food I never wanted to eat and then apologized for not having a hamburger or a fried chicken on hand, and I wanted to say that I didn't even like hamburgers or fried chicken, and that actually my favorite food was Chinese food, just not the Chinese food in China. After dinner, everyone was always talkative and I was quiet, not because I didn't have anything to say, but because I didn't want anyone to laugh at me or throw their hands up in the air at the absurdity of a Chinese person who couldn't speak Chinese. I didn't want to promise to learn perfect Chinese by my next visit to China because I still needed people in America to look at me and know instantly that I spoke perfect English instead of looking at me and assuming that I didn't know how just because I was quiet. 
My relatives in Shanghai thought I was lonely, or that I was sad, or that I didn't like it in Shanghai, or that I didn't like the food, or that I was bored with the television shows, or that I was unhappy with the bathrooms, the last of which wasn't so far from the truth since the bathroom in my grandmother's house really did smell of fecal matter. The smell prevented me from being able to stand being in the bathroom for more than a minute at a time, and also prevented me from being able to stay long enough to expel shit from my own body, and in the end I had to go to the hospital because I was so constipated that I gave myself a fever and cried the one time I thought I was finally going to do it, but it turned out to be nothing more than a massive fart. But other than that incident, I was all right. I was grateful to be near my family whom I hadn't seen in more than five years.

I was four and a half when my parents and I moved to New York. My mom ordered a phone line right away even though in the winters we could only afford heat at night. She called home to Shanghai all the time. In the beginning, my mom would put me up on a stool so I could reach the phone that was mounted on the kitchen wall and say into the receiver in Chinese, 156 "I love you grandpa, I love you grandma, I love you big auntie, I love you middle auntie, I love you small auntie, I love you uncle, I love you cousin, I love you favorite uncle, I love you auntie who just married my uncle, I love you cousin who I never met, I love you grandpa on my mom's side, I love you grandma on my mom's side, I love you great grandma and the spots of dirt on your head that look green in photos, I love you great auntie, I love you great uncle, I love you nephew who is older than me and who I never met and who is visiting us soon, I love you all and wish you the best health in the coming year." My mom would rehearse the speech with me over and over before calling my family in Shanghai, and even though I knew exactly what I was supposed to say into the phone, I never said a single word. My mother would take the phone from me and sheepishly say, "Did you hear her? She speaks very softly." I knew that I had failed somehow, even though I didn't understand at the time what was so dire about telling someone on the phone that you loved them-what made that more significant and profound than knowing that you felt it, a warm and settling love that heated your insides and worked its way into your dreams at night? I revisited that question every time my relatives pressed into me, every time they fussed over me, every time they waited for me to say something to relieve them of their fear that I would always be distant, that I would always move away from them.

THE IOWA REVIEW 
A few days after going to the hospital and taking so many laxatives that I couldn't sit down without tricking my butt into opening and thinking that I was going to take a shit, my cousin Jing sat down next to me after dinner (which I ate ravenously to the satisfaction of my aunts and uncles and grandparents) and asked me what sort of music I liked listening to. She was four years older than me; we had grown up together in my grandparents' house before I moved to New York. I didn't know her very well anymore. She talked with me about a popular boy band whose sixth member was a real live monkey, and as she was talking, I could tell that she thought I thought she was boring, and I could tell she wanted me to feel an alliance with her, and I could tell that she could tell that I didn't remember growing up with her and needing her all the time, and I could tell that she thought need was the basis of any familial relationship, and I could tell that it pained her whenever my grandmother mentioned the time my cousin drew my face in the dirt after I left for America with my parents, because when my grandmother told that story it never moved me the way it moved my grandmother, which was always to tears because it reminded her of all the times people in her life had left her, and because the repetition of disappearance followed by the diaphanous caprice of reappearance made her susceptible to being wounded at any moment, but as for me, none of it impacted me much, and I knew that my indifference disturbed my cousin greatly.

"You know," she said to me after a long silence during which we ate watermelon with seeds. I swallowed all the seeds and she picked them out, even the white ones, which were soft and nice to chew. "Once, when you were little, we took the train to the country and we had a picnic there. You wanted to go into this cave very badly. For some reason, your parents that day gave me permission to take you. You were overjoyed. I was happy too. It was nice to go exploring on our own for a while. At some point, we found a small river running through the inside of the cave. You wanted to hop over it like Sun Wukong. You were obsessed with Sun Wukong back then, remember? I told you never to try anything that Sun Wukong did. I said to you, Don't you know Sun Wukong isn't real? Don't you know that real people can't fly and pull down trees with their fingers? I remember telling you, Don't try to hop over it like Sun Wukong. You asked me why not, and then suddenly, there was a big splash and you were in the water. I knew you couldn't swim so I jumped in too and pulled you out."

"There are rivers in caves?" 
"Yes. There was one in this cave."

"And I fell in?"

"Yes."

"And you saved me?"

"Yeah, that's exactly what I did."

"You did?"

"I really did."

"Are you sure?"

"Yes."

"Did you just remember this?"

"No, I've always remembered."

"You never forgot?"

"No," she said. "No, how could I have forgotten?"

"I can't believe you saved me."

"I really did. You fell into the river, and I saved you."

We both laughed at how something like this could have happened, and after that I no longer looked at her and wondered what it would have been like to know her instead of just knowing that she was my cousin and I was hers because our mothers told us so. After that night, I felt like her cousin, and we were together every minute of every day until it was time for me to go back to New York with my mother. The next time we went back to Shanghai, my cousin and I were strangers again-I felt as warm towards her as fish to a frozen pond, and I tried to remember how it all felt two summers ago when we rediscovered each other, and I tried to remember how she saved me from drowning and how that meant we would always be close, but it was futile. My cousin and I were beginning to understand why our grandmother cried so often, and how there were so few options for coping with the tedious quality of the reappearances and disappearances that we would both continue to make in each other's lives.

\section{Reunion \#4}

No three people in my family live within one hundred miles of each other. We're all pretty much alone, and none of us calls or writes or does any of the things that a person does in the face of staggering distance. I live alone and have no friends because I don't know how to make anyone laugh but myself, and one afternoon, I buy sixty maps of the world and wallpaper my bedroom with them, placing little metallic thumbtacks to mark each family member, 
and at night, the tacks radiate faintly from the moonlight that comes in through my thin curtains and form a dotty outline of a new continent that I wish could exist solely for me and my family so at least none of us would have to cross water to reach each other. It's only a wish, and because there are so many silvery thumbtacks that glisten at night, I start to feel sad.

I keep track of everyone's ages because a long time ago, before we were all spread out on different hemispheres, different longitudinal lines and time zones, we agreed that we had to get together for my grandfather's ninetieth birthday if he was still alive. He's still alive, and when my grandfather's birthday approaches, I decide to grow what some people might think of as wings, but what I think of as a natural desire to collect my family members, which I do, sweeping down into the cities and towns and villages I've never been in before and pulling each person close to me for a brief moment before throwing them in a sack that holds up to forty tons of weight.

Hello, I say to each member of my family as I pick them up from their home or their place of work or the restaurant where they are having their lunch or the recreation center where they are shooting the shit about old times, and I say hello, hello, hello there, hello, remember me, I'm your cousin, remember me, I'm your niece, do you know me, I'm your second cousin, remember me, I'm your twice-removed cousin, have you heard of me, I'm your littlest aunt, remember me, I'm your great granddaughter, I'm your granddaughter, I'm your daughter, I'm your sister.

The answers I get are: no hi yes yes yeah yup jide bu jide nihao baobai I've missed you is it really you you can fly thank you do you speak Chinese you look old.

When I was three, I asked my aunts where humans came from and they started to talk about a woman opening up like a blossom for a man who loves her, and I said, No, no, no! I mean the first human being, where did he come from? My first aunt said, No one can really say, but I think, and my second aunt interrupted her and said, God created all of us, and my third aunt interrupted and said, The first humans came from monkeys. She then hunched her shoulders and lowered her arms and started to hoot like a monkey, and I jumped into her arms like she was my mom and these were just our normal bedtime games. When I scoop up my third aunt from the hospital in Tianjin where she works, she says to me, But do you know me, do you even remember how I was with you? I used to wipe your butt when you were a child, and I taught you about God and where humans came from. 
Monkeys, I said, we came from monkeys.

Yes, and also God, my aunt tells me.

I pick up my grandfather last. He's wearing a collar with no shirt attached. I worry that he will die from the cold before we get back to my house, and I realize when we are more than halfway there that everyone in the sack will die, and that right from the start, this has been a doomed venture.

We will all live to see this moment, I say into the bag of my family, when all of us are sitting around the table, eating and talking and letting the small days of living reconstitute our world. I wait for a reply but I don't hear anything back, and suddenly I am overcome with this feeling I used to get when I was younger and waiting for everyone to leave the house after a dinner party so that I could be alone, so that I could be awake while everyone else was sleeping, and then, for no reason at all, in the middle of piling my mom's sweaters on my head and dancing on my bed as if it were the shifting waters of the sea, I would be seized with a loneliness so stunning that I could only stand still, surrendering myself to it and replaying every moment of the previous few hours, reenacting all the conversations people tried to involve me in that evening, only this time, I responded with the words that I knew the people there were waiting for me to say, and I said them all, exactly as I knew how they were meant to be said, sounding them out in my head and whispering just the beginnings of each response out loud: Why thank you... I know what you...I also think so and it seems... Well my favorite... When I get older...I hope one day...I am especially fond...Sometimes I can't... You look very...You know what I miss...I love being...I'd like to try...It was really nice... But it's difficult for me...I can't always... You should see... Hahaha...I'm frightened... How to say this... Do you see how... That's very good advice...I don't want to be so...I was never sure...In the first place... You're very gracious...Thank you... Funny because I also.... And it went on like that until I forgot who I was and no longer felt lonely. 